SCIREA Journal of Economics

http://www.scirea.org/journal/Economics

February 12, 2022

Volume 7, Issue 1, February 2022

https://doi.org/10.54647/economics79282

\title{
On the global implications of Afghanistan's new economic and socio-political realities for economic and strategic risk management.
}

\author{
Poorna Pal ${ }^{1}$ and Sarkis Khoury ${ }^{2}$ \\ ${ }^{1}$ Glendale Community College, Glendale, CA 91208, USA; poornapal@yahoo.com \\ ${ }^{2}$ University of California, Riverside, CA 92521, USA; Sjkhoury1@att.net
}

\begin{abstract}
:
We examine here the global implications of Afghanistan's new economic and socio-political realities as an Islamic emirate. The risk management involved here not as much one of managing a simple economic and financial risk as of having to examine whether the rest of the world should merely watch how the current situation evolves there or explore the possibilities of whatever can be done to help manage the risk to the global order itself. As such, three facts readily stand out. One, the emerging Taliban regime is Pashtun dominated but the Pashtun nation actually straddles Afghanistan as well as Pakistan, particularly as the latter is now in a economically tattered state. Note that Pashtuns are the dominant ethnolinguistic group in multi-ethnic Afghanistan but over two-thirds of Pushtuns actually live in the neighboring Pakistan and most of the Pushtoons have never accepted this Britishimposed division of their land over a century ago. Two, despite all their protestations, the last time the Taliban ruled Afghanistan, during the 1996-2001 period, their most notable contributions to the world's harmony, peace and prosperity were the infamous, albeit involuntary, 9/11 bombings in the US, the deliberate destruction of 11th century AD Buddha
\end{abstract}


statue at Bamiyan, Afghanistan — a world heritage site, and the flogging and enslavement of women, that itself is a matter of grave global concern. And three, the geopolitical significance of this event and the likely spillover of terror into Afghanistan's immediate neighborhood and beyond make one wonder if 20-years exile have moderated Taliban's world view and governance-style and if its new dispensation feels any need to rebuild the nation and what kind of nation it really want to build. For all intents and purposes, the new Taliban 2.0 interim government looks like the reincarnation of its old Taliban 1.0 version and raises the spectacle that the world's never ending "War on Terror" is destined to continue. We examine these issues here and, hoping against all hopes that this time it may be different and unlike the COVID 19 pandemic that keeps returning again and again, we seek the seemingly utopian goal ${ }^{1,2}$ of starting afresh and ascertain as to what all the world can and should do, if at all, in order to help that hapless country and its new regime to at least economically stabilize.

Keywords: Failed States, Economic Risk Management, Managing Afghanistan Economy

\section{Introduction}

Afghanistan is a multiethnic society (Table 1) where Pashtun's are the dominant group but lack an absolute majority even if they all could unite. Tajiks, Hazaras and Uzbeks account for a slightly larger proportion of the population. This and a weaker national government perhaps contribute the most to Afghanistan's incessant inter-tribal strife, particularly because Afghanistan remains not as much a country as an inter-tribal amalgam.

Table 1: The socio-ethnic statistics of Afghanistan (taken from https://gulf2000.columbia.edu/images/maps/Afghanistan_Ethnic_lg.pn)

\begin{tabular}{lclclc}
\hline $\begin{array}{l}\text { Ethnolinguistic } \\
\text { Group }\end{array}$ & $\begin{array}{c}\text { \% of total } \\
\text { population }\end{array}$ & $\begin{array}{l}\text { Ethnolinguistic } \\
\text { Group }\end{array}$ & $\begin{array}{l}\text { \% of total } \\
\text { Population }\end{array}$ & $\begin{array}{l}\text { Ethnolinguistic } \\
\text { Group }\end{array}$ & $\begin{array}{l}\text { \% of total } \\
\text { population }\end{array}$ \\
\hline Pashtoons & 38.5 & Uzbeks & 6.2 & Turkemanis & 1.2 \\
Hazaras \& Sayyds & 24.5 & Aimarks & 3.2 & Baluchs, Pashai etc & 1.2 \\
Taziks \& Parsiwans & 21.3 & Arabs & 3.2 & Nuris & 1.0 \\
\hline
\end{tabular}

Afghanistan today is one of the poorest countries in the world, the tenth poorest economy according to the World Bank's per capita GDP (Gross Domestic Product) data in current US dollars for 2020. Table 2 shows this and the related data, drawn mainly from the World 
Bank's 2020 WDI (World Development Indicators) database, labeled as one of the LDCs (Least Developed Countries) by the United Nations.

Table 2: Some statistics about the world's ten poorest economies that Afghanistan belongs to under the UN classification of world economies.

\begin{tabular}{|c|c|c|c|c|c|c|c|c|}
\hline & \multirow{2}{*}{$\begin{array}{c}\text { per capita } \\
\text { GDP (US\$) }\end{array}$} & \multirow{2}{*}{$\begin{array}{l}\text { GDP (billion } \\
\text { current } \\
\text { US\$) }\end{array}$} & \multirow{2}{*}{$\begin{array}{c}\text { Population } \\
\text { (million) }^{a}\end{array}$} & \multirow{2}{*}{$\begin{array}{c}\text { Gini } \\
\text { Index }\end{array}$} & \multicolumn{2}{|c|}{$\begin{array}{l}\text { Life expectancy } \\
\text { at birth (years) }{ }^{C}\end{array}$} & \multirow{2}{*}{$\begin{array}{c}\text { under-5 } \\
\text { mortalitv } \\
\text { rate }^{a}\end{array}$} & \multirow{2}{*}{$\begin{array}{c}\text { Maternal } \\
\text { mortality } \\
\text { rate }^{a}\end{array}$} \\
\hline & & & & & Male & Female & & \\
\hline 1. South Sudan & 236 & 3.15 & 13 & 46.0 & 56.4 & 59.4 & $9.6 \%$ & $1.15 \%$ \\
\hline 2. Burundi & 310 & 3. & 11 & 38.6 & 59.8 & 63.4 & $.7 \%$ & $0.55 \%$ \\
\hline 3. Malawi & 367 & 7.44 & 20.29 & 44.7 & 61.1 & 67.4 & $4.2 \%$ & $0.35 \%$ \\
\hline 4. Central African Republic & 441 & 2.29 & 5.18 & 43.6 & 51.1 & 55.5 & $11.0 \%$ & $0.83 \%$ \\
\hline 5. Madagascar & 4.71 & 12.73 & 27.05 & 37.2 & 65.4 & 68.7 & 5 & $0.34 \%$ \\
\hline 6. Niger & 488 & 9.72 & 19.94 & 42.6 & 61.3 & 63.6 & $8.0 \%$ & $0.51 \%$ \\
\hline 7. Mozambique & 493 & 15.37 & 31.16 & 54.0 & 57.8 & 63.7 & $7.4 \%$ & $0.29 \%$ \\
\hline 8. Dem Rep of Congo & 495 & 48.46 & 97.88 & 42.1 & 59.1 & 62.2 & $8.5 \%$ & $0.47 \%$ \\
\hline 9. Sierra Leone & 517 & 4.00 & 7.74 & 34.0 & 53.9 & 55.5 & $10.9 \%$ & $1.12 \%$ \\
\hline 10. Afghanistan & 548 & 19.99 & 36.51 & 29.4 & 63.4 & 66.4 & $6.0 \%$ & $0.64 \%$ \\
\hline World & 10,925 & $88,080.00$ & 7870.00 & 65.0 & 70.6 & 75.0 & $3.8 \%$ & $0.02 \%$ \\
\hline
\end{tabular}

a 2017-2019 World Bank estimates (retrieved from httbs://databank.worldbank.ora/).

b https//worldpopulationreview.com/country-rankings/gini-coefficient-by-country retrieved on Sept 2, 2021

The world data is from https://en.wikipedia.org/wiki/Gini_coefficient retrieved on Sept 2, 2021

c https:// www.worlddata.info/life-expectancy.php

This no doubt reflects the toll that years of incessant warfare have inflicted on the country and its people. Lack of infra-structure and security, conflict and internal strife are therefore the most visible culprits here ${ }^{3,4}$. But the problem goes much deeper, most particularly because Afghanistan has witnessed war ever since the 1979-1989 Russian invasion and the 2001-2021 US intervention. Even before then, lack of infrastructural development was what had contributed the most to the ouster of Afghanistan's last and longest ruling king, Mohammed Zahir Shah (reign: 1933-1973), in a coup d'état by his own cousin and premier, Sardar Mohammed Daoud Khan (reign: 1973-1978), who became the president of a single-party republic that ended over 225 years of what had been the longest continuous monarchical government in this country's history. Indeed, the founder of modern Afghanistan, Emir Abdur Rehman Khan (reign: 1880-1901) never allowed railways and telegraphs because he wanted to prevent foreigners (at that time the British and the Russians) from gaining a foothold within Afghanistan.

Also note that seven of these ten countries in Table 2 are geographically land-locked ${ }^{5}$, many are resource-rich and therefore susceptible to the vagaries of the market (e.g., Congo and South Sudan), some to the vagaries of nature (e.g., Sierra Leone) and some have bad neighbors (e.g., Afghanistan ${ }^{6}$ ) 


\section{Afghan economy now and in the past 50 years:}

Afghanistan's socio-economic history has become particularly turbulent since the fall of the monarchy. Of the numerous barriers to Afghanistan's economic growth ${ }^{7}$, poor infrastructure, human capital inadequacies, primary product dependency, declining terms of trade, savings gap; inadequate capital accumulation, foreign currency gap and capital flight, corruption, poor governance, impact of civil war and population issues are the most notable. Take the last named of these, the population, for instance. In recent times, the population growth rate had peaked during Taliban 1.0 and has been declining since then, perhaps because of first peace and stability and then war and mayhem (Figure 1). If true then Taliban 2.0 augurs ill for the future of an already fast growing population and will strain the already inadequate healthcare and related facilities for the women and children. As the World Bank reports, conflict, poverty, poor health services, high birth rate and low levels of female education and rights also combine to produce extremely high mortality rates for Afghan newborns, older infants and very young children. Taliban policies are only likely to aggravate this problem, not resolve it, and the evidence so far only reiterates that it's medieval governance style will probably continue. Ordinarily, this seems well designed to ensure the world's indifference whereas the rest of the world can neither ignore this problem nor interfere directly. Clearly, the Taliban government has neither the will or foresight nor the required money in order to tackle this problem, more because it does not even recognize that a problem like this really exists.

An equally immediate and directly related evidence is seen in the GDP data and the corresponding growth rate. As shown in Figure 2, Afghanistan's GDP had been growing since the early 2000 but has remained steady since about 2015, and its corresponding per capita GDP has been actually declining. So much for average Afghan's prosperity during the theoretician ex-President Ghani's tenure! Interestingly, it is this period of declining growth rate that may well have eroded the civilian government's popularity and strengthened the resurgent Taliban who were waiting in the wings, so to speak. 
Figure 1: Since about 1990, Afghanistan's population has been growing faster than that of the other less developed economies (source: https://worldpopulationreview.com/countries/afghanistan-population)

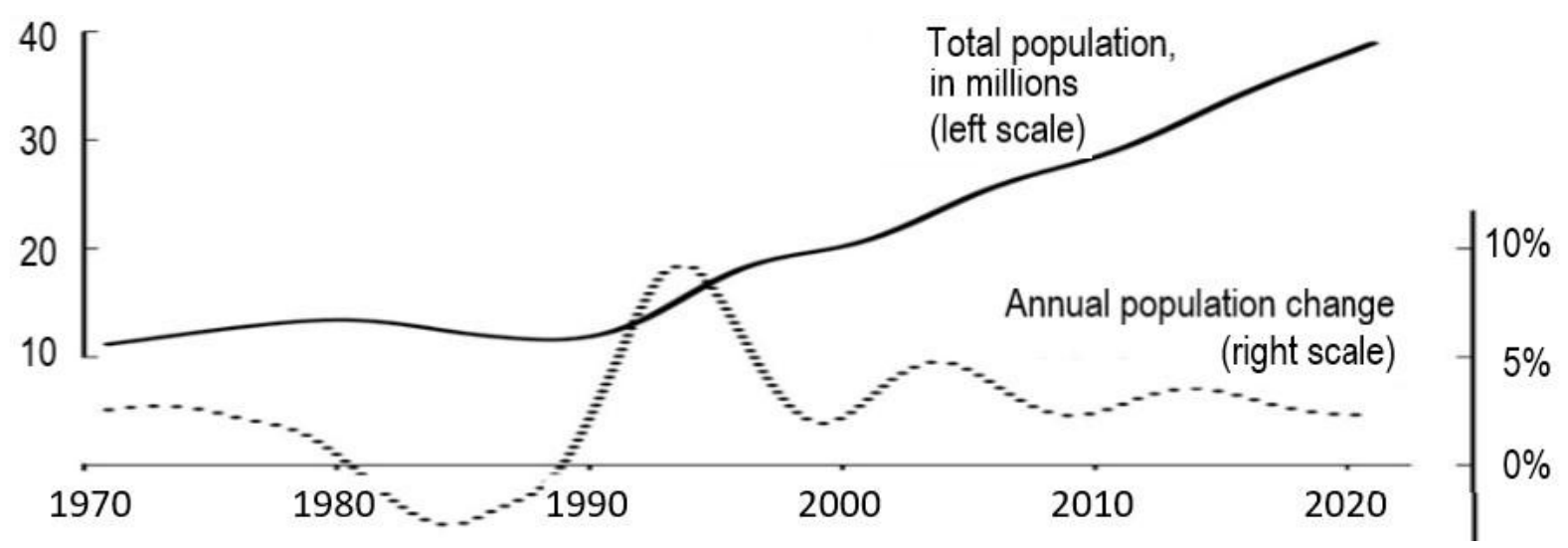

Figure 2: Afghanistan's GDP and corresponding per capita GDP and GDP growth rate data (source: World Bank's "World Development Indicators" database)

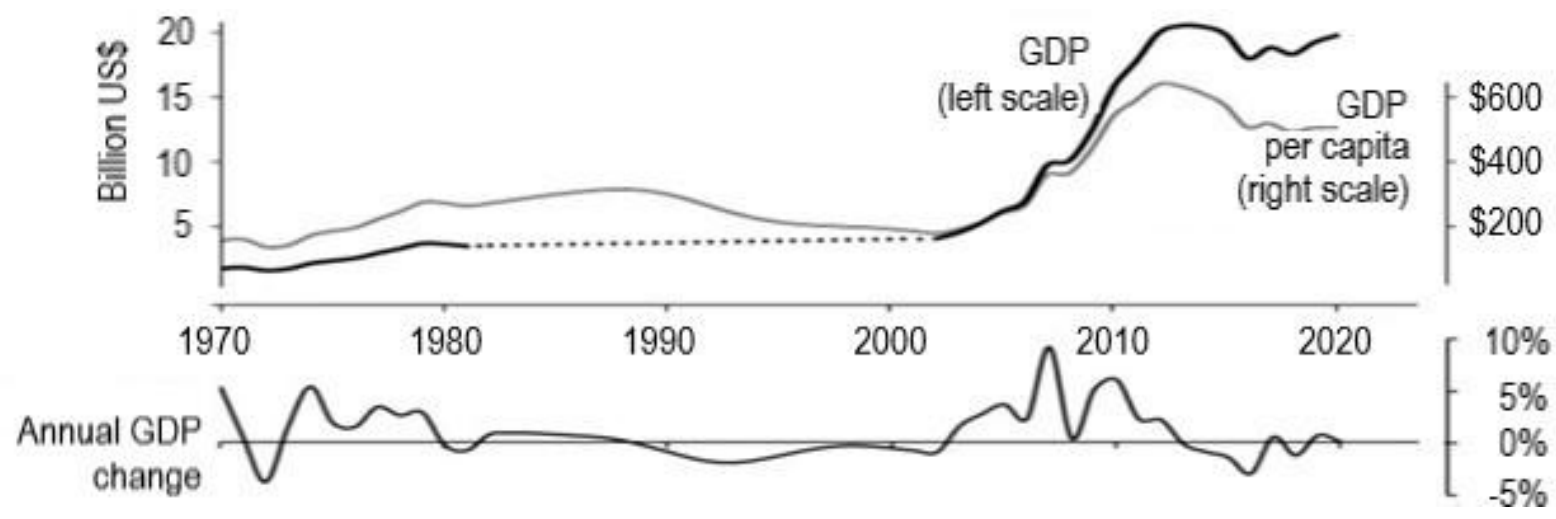

This justifies the US Aid claim ${ }^{8}$ that US collaboration has helped raise the Afghan per capita GDP from \$21.80 in 2002 to $\$ 647$ in 2018". Indeed, it is the influx of foreign money that has basically funded Afghanistan's welfare throughout these past two decades. Without American intervention, the linear extrapolation of 1980-2001 trend gives the Afghan per capita GDP as about \$300 in 2021.

\section{The economic impediments to Afghanistan's future growth:}

Of all our earlier enumerated measures needed for Afghanistan's economic growth, viz., poor infrastructure, human capital inadequacies, primary product dependency, declining terms of trade, savings gap, inadequate capital accumulation, foreign currency gap and capital flight, corruption, poor governance, impact of civil war and population issues, good governance is perhaps the only issue that Taliban 2.0 can at best be able to address. Judging from its 
dependency on the neighboring bankrupt Pakistan's military help for government formation and to try to subdue its erstwhile foe, the remnants of the pre-Taliban 1.0 Mujahideen of the Panjshir Valley ${ }^{9}$, and the ongoing conflicts within the Taliban, it is doubtful if Taliban 2.0 can arrest capital flight and outward flight of the skilled populace who can help build the country and attract foreign capital.

As such, the Human Capital Index (HCI) of Afghanistan — an index designed by the UNDP (United Nations Development Program) to measure the amount of human capital that a child born today can expect to attain by age 18, given the conditions of mortality, health and education now prevalent in the country of domicile - is very low (Figure 3 ). This index is a product of three normalized $0-1$ scales for contributions to productivity as a future worker: survival, schooling and health and is measured on a $0-1$ scale, so the closer it is to one the better the prospects for the future of a nation's economy.

Figure 3: HCI data for Afghanistan and the other countries versus their GDP data in constant

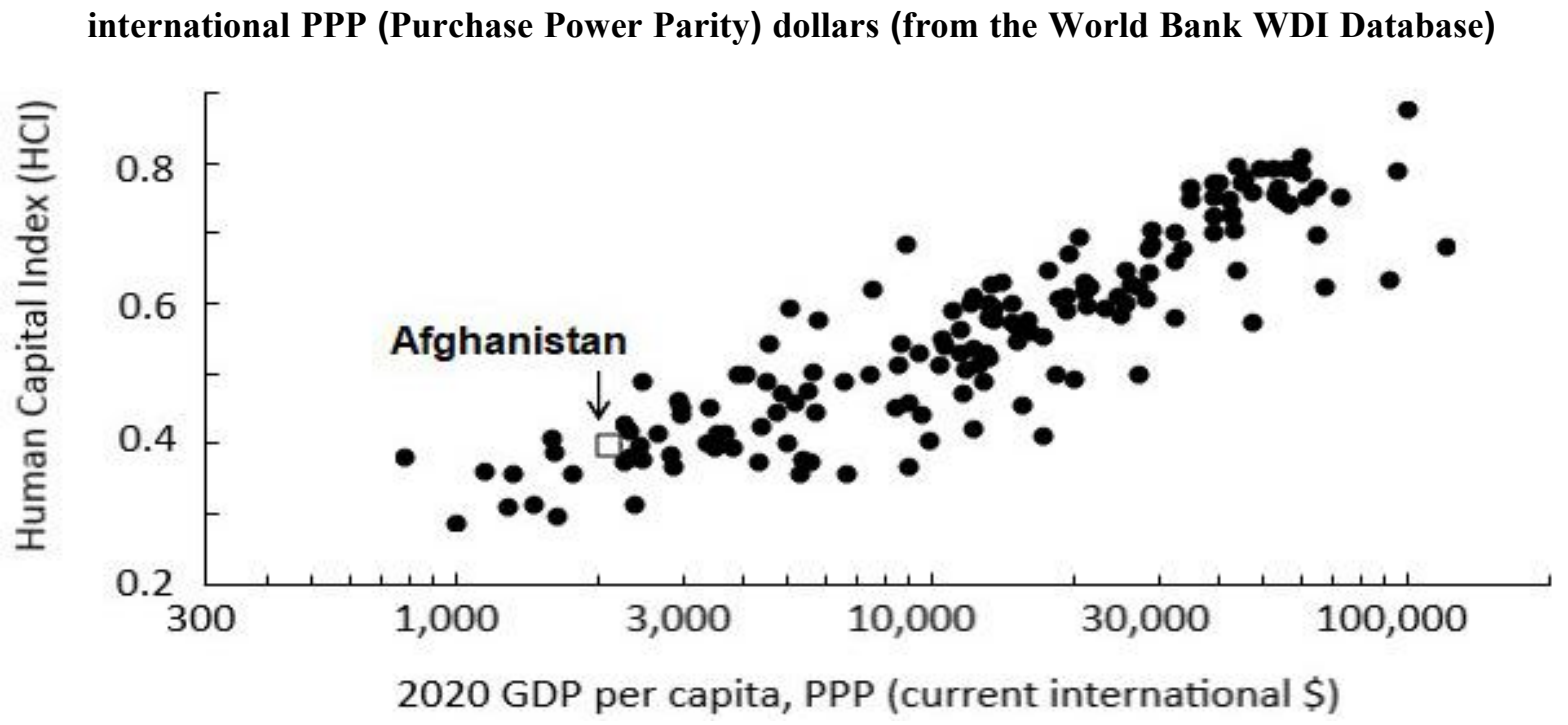

The poor HCI of Afghanistan thus means that the regime can ill-afford the continuing outflow of educated and skilled amongst its citizenry. But then, since when are the autocratic and theocratic to semi-theocratic regimes ever seem bothered by such niceties? South Sudan and Iran are the examples that immediately come to mind here.

The funding situation in Afghanistan is also dismal. Figure 4 below summarizes the external funds-flow statistics for the country, for instance. Afghanistan has traditionally been a net importer, with total exports of $\$ 2.24$ billion in 2019 , while the corresponding imports were $\$ 6.92$ billion $^{10}$. These exports mostly comprised gold, grapes, resins, nuts and fruits and the imports were mostly wheat flour, broadcasting equipment, petroleum products, rolled tobacco and aircraft parts. Compare this negative trade balance with the net overseas 
developmental assistance of $\$ 4.44$ billion and we can well imagine how dire the plight of the new regime will be if it seeks to sustain the same quality of life. But the sad truth is that for most of the Afghans the loss of overseas assistance will make little difference because much of the imports and overseas funding probably got usurped up by the so-called elite. The casualty will be the net developmental gains that the IBRD (International Bank for Reconstruction and Development) has reported ${ }^{11}$ as having indeed been substantial.

Figure 4: Afghanistan's net cash outflow

(sources: https://oecd.world/en/profile/country/afg\#historical-data and the World Bank's WDI database)

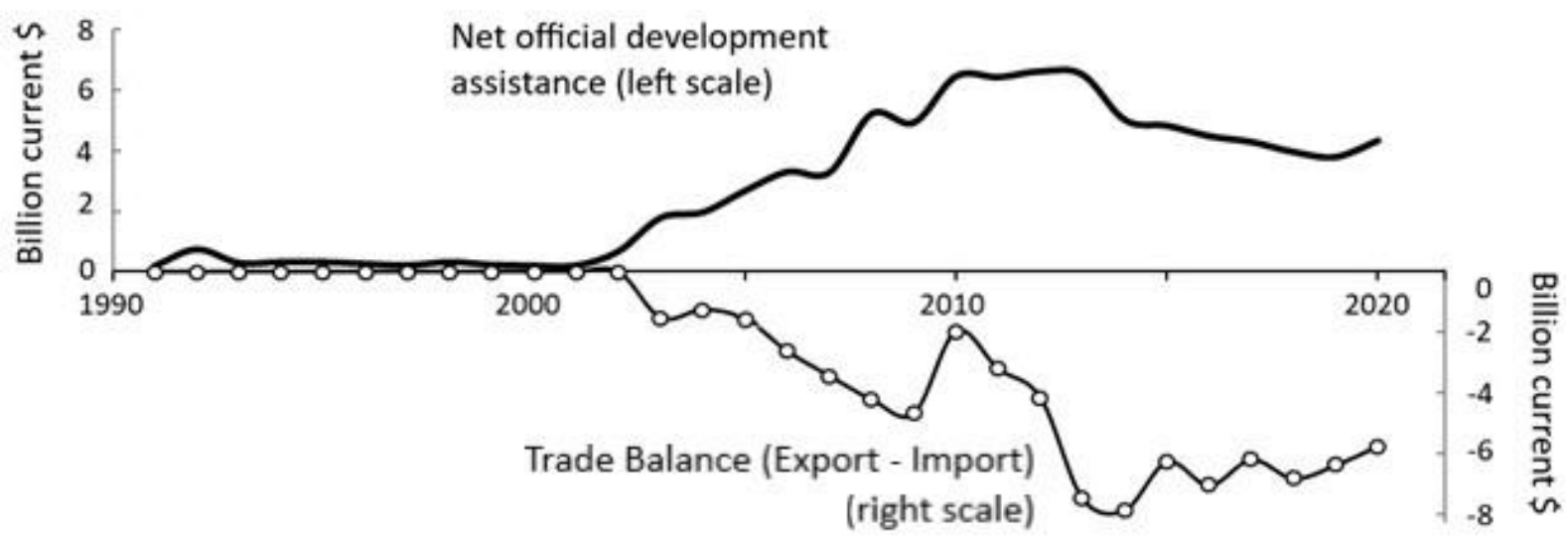

For the sake of completing this scenario, we do need to also consider Afghanistan's FDI (Foreign Direct Investment) and mineral resources. As for the former, though, the country's record is rather dismal and apparently inconsequential for its economy. World Bank's data show that even in 2019 Afghanistan received a paltry \$234 million in FDI, compared to $\$ 187$ billion for China, $\$ 51$ billion for India, and \$2 billion for Pakistan.

Likewise, as for the mineral resources, it is often argued that Afghanistan is rich in mineral resources ${ }^{12}$. Indeed, the country straddles the tectonic boundary of the Indian plate ${ }^{13}$ and such boundaries are often rich in metallic, hydrocarbon and geothermal resources ${ }^{14}$. Some have even argued that such natural resources have made the war in Afghanistan profit driven ${ }^{15}$ and during the pre-Taliban 1.0 days, Ahmad Shah Masood's Northern Alliance is believed to have sold \$40-60 million worth of lapis lazuli annually ${ }^{16}$. But it is doubtful if even finding Lithium, now in heavy demand for electric car batteries, will add much luster to the country's mineral exports, \$19 million world-wide in 2019. 


\section{What if Afghanistan is truly a "Failed State"?}

For all practical purposes, therefore, Afghanistan is already a failed/fragile state. The American think-tank Fund for Peace (www.fragilestatesindex.org) and Foreign Policy magazine (https://foreignpolicy.com/) annually publish a 'Fragile States Index' (FSI) that, according to The Economist magazine (https://www.economist.com/the-economistexplains/2021/09/02/what-makes-a-failed-state), seeks quantifying how close a state is to failure, by scoring every country based on indicators like economic decline, security apparatus, public services, and human rights and rule of law. As shown in Table 3 here, this apparently semi-quantitative albeit arbitrary measure has continually ranked Afghanistan amongst the ten worst states in the world, ever since the inception of the index in 2006.

Table 3: Afghanistan's FSI ranking and scores since 2006, as published by the Fund for Peace organization (www.fragilestatesindex.org) and the Foreign Policy magazine

(https://foreignpolicy.com/).

\begin{tabular}{|c|c|c|c|c|c|c|c|c|c|c|c|c|c|c|c|c|}
\hline & ஜ & 응 & \&્స & : & 음 & $\bar{\delta}$ & $\stackrel{N}{\stackrel{N}{N}}$ & $\frac{m}{\delta}$ & $\stackrel{+}{\check{D}}$ & $\frac{n}{\delta}$ & $\stackrel{\oplus}{\circ}$ & $\frac{\wedge}{\delta}$ & $\stackrel{\infty}{\delta}$ & $\frac{\infty}{\delta}$ & ్ㅗ & $\overline{\widetilde{N}}$ \\
\hline $\begin{array}{r}\text { FSI } \\
\text { Rank }\end{array}$ & 10 & 8 & 7 & 7 & 6 & 7 & 6 & 7 & 7 & 9 & 9 & 9 & 9 & 9 & 9 & 9 \\
\hline $\begin{array}{r}\text { FSI } \\
\text { Score }\end{array}$ & $\begin{array}{l}\infty \\
\text { ळं }\end{array}$ & ֻั & 륨 & ָֻ & लூ & 웅 & 움 & $\hat{\ddot{\theta}}$ & $\begin{array}{l}n \\
\ddot{8}\end{array}$ & 옹 & 옴 & 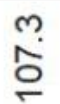 & $\begin{array}{l}\mathscr{\varphi} \\
\ddot{\varnothing}\end{array}$ & 웅 & ণ̊ & ธิ่ \\
\hline
\end{tabular}

The reliability of this index remains open to question, however. In 2009, for instance, the then Finance Minister and subsequently the President of Afghanistan, Ashraf Ghani ${ }^{17}$, coauthored a book on what to do about a failed state that no less an authority than Francis Fukuyama hailed as "a comprehensive framework for understanding the problem of statebuilding". The irony is that Ashraf Ghani resigned and fled the country on the Taliban's return in August 2021. So much for the two decades and \$2.5 trillion of American intervention, not to speak of the lives lost, to save Afghanistan from itself!

Now, Gibbon himself, in his seminal treatise "The History of the Decline and Fall of the Roman Empire"18 had ascribed that empire's fall to foreign invaders ("barbarians at the gate"), religion ("Rome had become clerical") and the promiscuous avarice of the elite, the last of which Piketty ${ }^{19}$ has recently discussed as inequality, among others. All these vices do exist in good measure in Afghanistan. 
But Afghanistan has a very long history of poor social infrastructure, inadequate public health services and public security, and now stands bankrupt as well. But so do many others, as the summary of top 30 or worst FSI countries in Table 4 shows.

Table 4: A summary of the world's top 30 most fragile countries. These FSI data are from the Fund for Peace organization (www.fragilestatesindex.org) and Foreign Policy magazine (https://foreignpolicy.com/) and the GDP, population and HCI data are from the World Bank's WDI database.

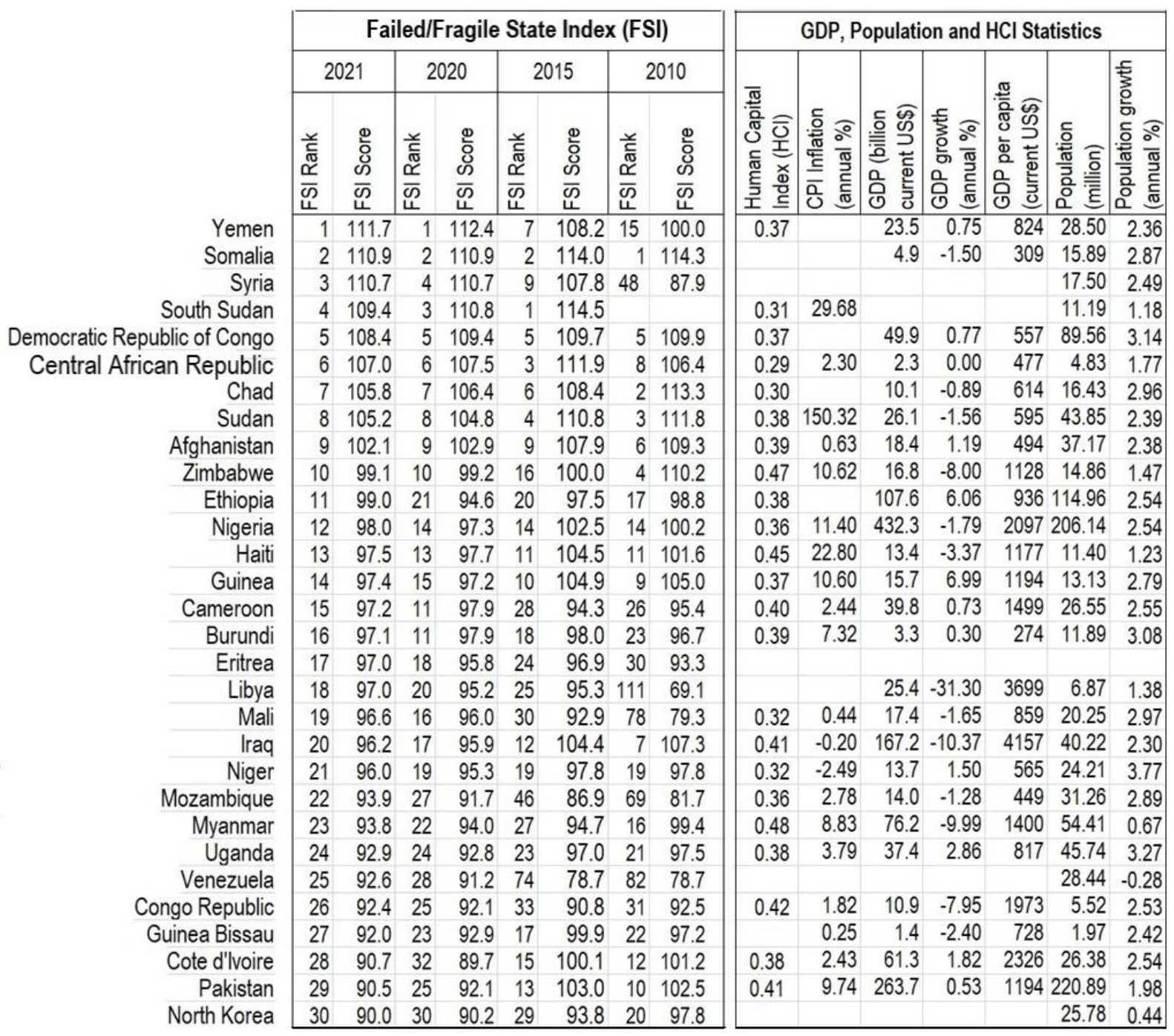

Note here that the nuclear-armed North Korea has continued to flirt with fragility throughout the life of this index, Sunni Saddam Hussein failed to survive and continue ruling the mostly Shia Iraq whereas Shia Asad's mostly Sunni Syria survives despite a shattered economy, over half a million dead or missing and over 13 million displaced Syrians. Sudan has continued to be on this list that South Sudan has joined, so dashing Sudan's hope of leaving this list even after granting independence to South Sudan. All these mean that Afghanistan too will survive, albeit as perhaps the poorest country in world, just as Yemen and Somalia are 
surviving. A weakness of this index also is that conflicts are endemic to the often fissiparous multiethnic societies and this contributes to their getting listed higher on their fragility status.

\section{The winners and the losers:}

So why should the world care? It all depends on who are the winners and who are the losers in the current Afghan scenario? As for the Taliban who were then ruling and got driven out in 2001 and are now back as the invaders, the US led forces who came for Ben Laden and his Al Qaeda terrorists, have packed and gone. The US intervention was in pursuit of the war on terror, and not on the Taliban government itself, and the reason for driving the Taliban out was their refusal to hand over the Al Qaeda jihadis to the US. The fact on the ground now is that the US led intervention somehow got morphed into nation-building and societal development and rebuilding efforts and that these efforts now lie in shambles. Part of the reason for this is that the Pashtuns and the other Afghan tribes are fiercely traditional, strongly independent-minded, and thoroughly resistant to any external intervention. Nonetheless, there are compelling reasons why we should remain concerned about whatever transpires there. Also note the pessimism of many US officials about whether the Afghan war was indeed winnable ${ }^{20}$ at all.

The world has so far left Afghanistan mostly alone. Neither Alexander the "Great" (some believe that many of today's Pashtuns have descended from those of his soldiers who refused to return), nor Chengis Khan and his Mangol hoards, or Taimur Lane for that matter, conquered the Pashtuns or found anything to plunder or occupy their land. True, the British India tried for a while and fought several supposedly unsuccessful wars. But how to call their efforts unsuccessful when, in the end, the Pashtun population got divided between Afghanistan and the then British India and now Pakistan (Figure 5)? Durand Line, a 2,640 km border between Afghanistan and now Pakistan supposedly demarcates the two regions and was agreed to between Abdur Rehman Khan, the then Emir of Afghanistan (reign: 18801901) and Sir Henry Mortimer Durand, a secretary of the British Indian government. While Emir Abdur Rehman Khan is often regarded as the founder of modern Afghanistan ${ }^{21}$, many also regard him as a tyrant and many more as the divider of the Pashtunland. Note that, excepting Amir Habibullah Khan in 1905 and Sardar Mohammed Daud Khan in 1976, no Afghan leader or government, not even the Taliban, have accepted the Durand Line ${ }^{22}$. Table 4 gives some relevant statistics about the Pashtun demographics. 
Figure 5: Map of Greater Pashunistan showing the Durand line that divides the Pashtun-speaking region between Afghanistan and Pakistan. The Pashtun-speaking region is shown in gray.

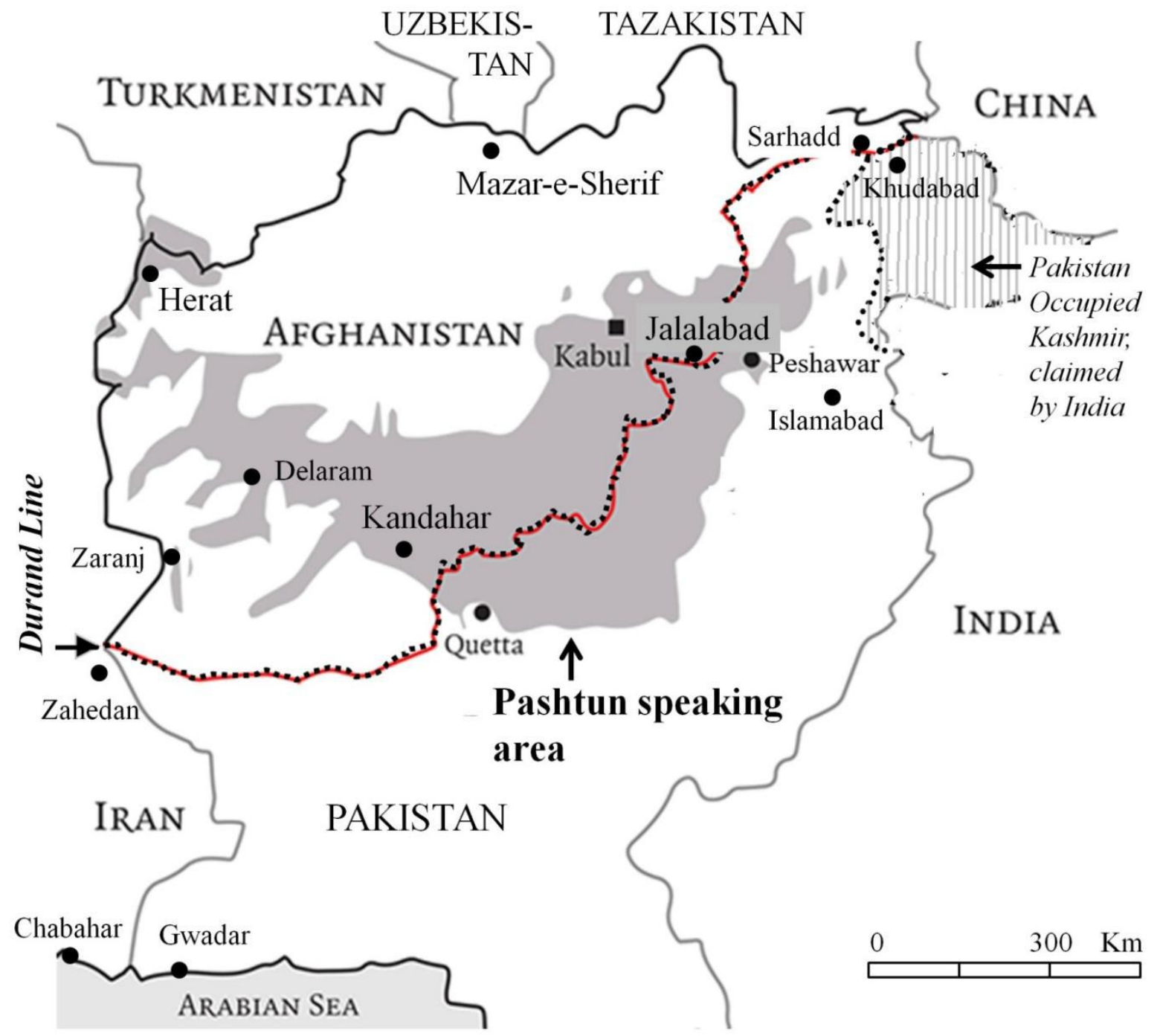

Adapted from: https://thestrategybridge.org/the-bridge/2017/8/25/the-case-for-an-afpak-fata

Table 4: Pashtun demographics (source: CIA The World FactBook)

\begin{tabular}{rcc}
\hline & Afghanistan & Pakistan \\
\hline Number of Pashtun speakers, in millions & 15.4 & 35.0 \\
Pashtun speakers, relative to the country's total population & $42 \%$ & $15 \%$ \\
Proportion of the total Pashtun population worldwide & $31 \%$ & $69 \%$ \\
\hline
\end{tabular}

Clearly, Pakistan is the only country so far that seeks to benefit from its supposedly pliant client that its authorities believe Taliban to be, hoping to finally succeed and demarcate its northern boundary. The problem is that no regime, no matter how it secures power, can sustain its legitimacy without the support of the governed. Having seen limited success in 
securing that through its own version of Islam during the 1995-2001 period, with little to no funds at its disposal for the required developmental efforts, and not even having the vision of what such efforts are likely to accomplish, appealing to Pashtun nationalism can easily become the mantra for the new Taliban 2.0 regime to motivate the populace it seeks to govern. And, that bodes ill and not well for Pakistan, even though many in Pakistan are now celebrating Taliban's return of power in Afghanistan. The efforts to create divisions within the new regime and so ensure that it remains compliant to Pakistan's strategic goals is what Pakistan is therefore striving for. The signs so far clearly point to that.

As for Afghanistan's other neighbors, Taliban 2.0 only obliquely presents any dangers to them as yet. Iran already has the IS-K (Islamic State - Khorasan) active in its north-eastern corner, China has its own Uyghur Muslim problem in Xinjiang even though it also hopes to gain some contracts and the like through its "all-weather" ally Pakistan, Russia has the memories of Chechnya to nurse, and India has to brace the invigorated Jihadi terrorism, most particularly because of Sirajuddin Haqqani and his network, India's arch antagonist and proxy for ISI - the Pakistani intelligence agency, who are deeply entrenched in the new Afghan regime. There already are reports of violence between it and Mullah Abdul Ghani Baradar's more moderate faction that negotiated the deal with the US in Doha.

There are two likely outcomes of these. One, if Taliban's supposedly moderate faction wins, then it will have to face pinpricks from the extreme Jihadi elements. That will be more like the way Palestians on the West Bank are pitted against those in Gaza and neither can vanquish the other. Peace will be a guaranteed casualty, nonetheless. Two, faced constantly with such bickerings from its more extreme faction, the supposedly moderate faction may well add nationalism to its religious fervor. In that case, first Pakistan and then Iran will get engulfed. Pakistan because its undemarcated northern border may finally disappear and Iran because the Baluch in Iran's Sistan-Baluchistan province may find a common cause with those in Pakistan. How about China and India? Well, China's focus is on the silk road but that bisects India's dream road through central Asia. But physiography can help China meander through a better course here and technology can help India find a better route to central Asia.

As for any international funding, Pakistan is almost bankrupt, China's economic model fuses Shakespearean Shylock with Mercantilism of Europe's $16^{\text {th }}-19^{\text {th }}$ centuries' protoindustrialization era, and Iran and Turkey have pride and ambitions but lack the financial wherewithal. Looking at the Taliban 2.0 Government itself, most of its leading lights remain 
on the UN blacklist, the Prime Minister is the one who had ordered the destruction of Bamiyan Buddha statues, and the Interior Minister is on the FBI's "most wanted" list. Do they have the credit-ratings to attract the much-needed foreign aid?

Samuel Huntington ${ }^{23}$ had predicted people's cultural and religious identities as the primary source of conflict in the post-Cold War world and the return of Taliban 2.0 amply testifies to that. Even Fukuyama ${ }^{24}$ despite his primarily linear, Hegelian view of history, had argued that Islam's poor intellectual and emotional appeals past the Islamic "heartlands" will either make those countries become democracies or they will simply disintegrate. Thus examined, it is not unlikely that even if a moderate and nationalist Taliban finally helps merge Afghanistan with Pakistan and create an Islamic behemoth, in the long run it will either implode or become a weak liberal democracy.

Today, barely a third of all Pashtuns live in Afghanistan though, and the rest in Pakistan. Even if a conservative, Islamist but presumably benevolent Mullah Baradar's Taliban captures the imagination of a third of the Pakistani Pashtuns by arousing Pashtun nationlism, it will become an unassailable champion of all Pashtuns, weaken the Durand line, and thwart all Pakistani machinations on Afghanistan's southern border. True, Pakistani Pashtuns are a motly assortment of desperate groups. They include TTP (Tehrik-i-Taliban Pakistan), PTM (Pashtun Tahafuz Movement), TLP (Tehreek-e-Labbaik Pakistan), NDM (The National Democratic Movement), ANP (Awami National Party), for instance, and many Pashtuns directly identify themselves with the mainstream parties like PTI (Pakistan Tehreek-e-Insaf), PML-N (Pakistan Muslim League - Nawaz Sharif) and PPP (Pakistan Peoples Party). Some are militant and others moderate, some are Barelvi sunnis but most are Deobandi Sunnis. The goal for the so-called supposedly progressive Talibans would then be to ignite their national pride as Pashtuns. After all, the nuclear-armed Pakistan too remains pretty high on the FSI list. Note that Pakistan has already had to make peace with the $\mathrm{TLP}^{25}$ during a recent clash of wills, plausibly mediated by Afghanistan's Taliban.

But the biggest danger to the rest of the world is simply this. Suppose the UN's World Food Program undertakes the most humanitarian task of feeding the millions of poor and hungry Afghans, hopefully thanks to the help from the world's superrich philanthropists ${ }^{26}$ like Microsoft's Bill Gates, Tesla's Elon Musk and Amazon's Jeff Bezos. This assumes, though, that Francis Fukuyama's "End of History" has really come. 
For instance, this year seems particularly different for Pakistan with the rise of the far right religious extremists like Tehreek-e-Labbaik (TLP) and Tehreek-e-Taliban Pakistan (TTP $)^{27}$ that only had to start a week-end to a week or two of protests to coax the government to succumb from its earlier hard stand and negotiate deals with them. This is barely a few months since the old euphoria of mid-wifing the nascent Afghan emirate. It also looks like the new Taliban 2.0 emirate may well end up with fluid borders in the south as well as the north. The latter is particularly ominous because not including the other ethnic groups like Uzbeks, Taziks and Hazaras - apparently consistent with the Pashtun tradition started by the 1880-1901 reign of Emir Abdur Rahman Khan who is believed to have killed, enslaved or forced the emigration of half the Hazara population - because of which many joined the anti-Taliban "Northern Alliance". This may well enable a resurgent Daesh.

Reasons like these should compel the rest of the world to help rescue the crumbling Afghan economy. Apart from the emergency food aid, the possible measures that are available include developing the health and transport infrastructures. As for the latter, we can hardly overlook the need to help that country open roads for trade with the world outside. The most crucial help here would be in terms of transport and transit facilities. But despite the trade pact with Pakistan for this purpose - Afghan Transit Trade Agreement (ATTA) and Afghanistan Pakistan Transit Trade Agreement (APTTA) - the Pakistani authorities have generally been unkind to their landlocked neighbor ${ }^{28}$. India therefore focused on am alternate route to send her goods to Afghanistan, and get the Afghan goods to India by circumventing Pakistani territory altogether and build the $218 \mathrm{Km}$ Delaram-Zarani road linking it to Zahedan in Iran at a cost of $2.6 \mathrm{Km}$ per million dollars. The US Agency for International Development (USAID) too has likewise focused on road-building, albeit for about $2 / 3 \mathrm{Km}$ per million dollars. These are the activities that will now need to continue.

\section{Concluding Remarks:}

Economic growth requires wealth creation and religious zealots promise prosperity in the after-life. So, Afghanistan's economic future remains uncertain, much like it's as-yet unfinished "ring road".

It's for no reason that economics is called a dismal science. Afghanistan's dismal economy suggests even more dismal prospects of adequate resource availability for building public and health infrastructures. What can the rest of the world do in such a milieu? But the lesson 
of COVID pandemic is that so long as the virus exists in any corner of the world, the rest of us can ill-afford to ignore it. Jihadi or any kind of terrorism too is precisely that and our task is to eradicate it with its roots. The problem is that, without adequate resources, setting such a task seems like signing up for abject failure.

Economic future will obviously require Afghanistan's stability, and without that this country will remain the world's most dangerous place and a potential incubator of Jihadi activities. Stability is what Taliban 2.0 will very likely provide, though, much as Taliban 1.0 did, perhaps by chopping some hands and beheading some women, although it is doubtful if this method of femicide is any less or more merciless than the practice of stoning to death that prevails in Saudi Arabia and elsewhere. But such brutalities are hardly unusual in Afghanistan's historic context. The 1979-89 Soviet intervention saw over a million Afghans killed, for instance. Emir Abdur Rahman $\mathrm{Khan}^{29}$, the founder of the modern Afghan state, likewise crushed the 1884-1905 Hazara rebellion by killing $60 \%$ of the Hazaras who now comprise almost a quarter of the Afghan population.

In addition to political stability, though, economic future will require ending current Afghanistan's endemic corruption and garnering internal and external funds. Here, the likely harsh measures of Taliban 2.0 can well lower the level of corruption which a recent study ${ }^{30}$ ascribes to the funding windfall during these two decades long American intervention. This study prescribes using narrative, custom, pride, and tradition to instill national consciousness. But then, as we have mentioned earlier, this is the very tool that Taliban 2.0 will perhaps use to galvanize Pashtun nationalism in order to accomplish the cherished Pashtun dream of Greater Pashtunistan. And that wouldn't cost a penny! But garnering the required funds is going to be well nigh impossible, for the reasons we have explained earlier. Taliban 2.0 clearly understands this and is therefore seeking donations, not loans, if the recent reports are to be believed. Receiving gifts and grants from Islamic charity organizations and development assistance from the UN and its agencies would then seem to be the best bet for the new regime at this juncture. That will slow down the economic growth rate but not let the economy collapse outright. Welcome to the world of Taliban 2.0! 


\section{References}

[1] Jensen, D. and Lonergan, S., Ed (2012): "Assessing and restoring natural resources in post-conflict peace-building" Routledge, Taylor \& Francis (Pubs.) 536 pp. https://undocs.org/pdf?symbol=en/A/CN.4/728

[2] Jehanzeb Khalil, Saima Perveen, Zahid Ali and Zahid Shah (2015): Afghanistan's Political and Economic Condition: An Appraisal of Likely Situation at NATO-Drawdown, FWU Journal of Social Sciences, Special Issue, Summer 2015, Vol.1, No.1 (https://www.academia.edu/32376305/Afghanistans_Political_and_Economic_Condition _An_Appraisal_of_Likely_Situation_at_NATO_Drawdown)

[3] Hunzai, K; Gerlitz, JY; Hoermann, B (2011) Understanding mountain poverty in the Hindu Kush-Himalayas: Regional report for Afghanistan, Bangladesh, Bhutan, China, India, Myanmar, Nepal, and Pakistan. Kathmandu: International Centre for Integrated Mountain Development (ICIMOD). (https://lib.icimod.org/record/9376).

[4] Ochilov Akram Odilovich and Ehsas Najibullah (2021): "How to Reduce Poverty in Afghanistan", Academic Journal of Digital Economics and Stability.

[5] Paul Collier (2007): The Bottom Billion, Oxford University Press (ISBN-13: 9780195373387).

[6] Ahmad Shoaib Rahim (2018): Afghanistan's Dependence on Pakistan: Trade, Transit and the Cost of Being Landlocked, Kardan Journal of Economics and Management Sciences, vol 1, pp. 38-48 (https://kardan.edu.af/Research; DOI: 10.31841/KJEMS.2021.68)

[7] Tom Arnold and Krisztian Sandor (2021): "Crisis pushes Afghanistan's economy closer to the brink" (https://www.reuters.com/world/asia-pacific/crisis-pushes-afghanistanseconomy-closer-brink-2021-08-20/)

[8] https://www.usaid.gov/afghanistan/economic-growth (retrieved on Sept 8, 2021)

[9] Conner, Tobin (2020): "The Myth of the 'Afghan Trap': Zbigniew Brzezinski and Afghanistan, 1978-79". Diplomatic History, 44: 2, 237-64 (DOI: https://doi.org/10.1093/dh/dhz065; https://hdiplo.org/to/AR966).

[10] https://oec.world/en/profile/country/afg\#historical-data retrieved on Sept 12, 2021.

[11] Haque, Tobias (2020): Afghanistan's Development Gains : Progress and Challenges. World Bank (https://openknowledge.worldbank.org) 
[12] John Schroder (1983): 'The USSR and Afghanistan Mineral Resources' chapter 6 in "International Minerals - A National Perspective": Edited by Allen F. Agnew, Published by Routledge.

[13] P.C. Pal (1972): Global Plate Tectonics - Boundary of the Indian Plate, Current Science, 41, 704-706.

[14] Peter A. Rona (1983): Potential Mineral and Energy Resources at Submerged Plate Boundaries, Natural Resources Forum, 7, pp. 329-338.

[15] Michel Chossudovsky (2014): ' The War is Worth Waging : Afghanistan's Vast Reserves of Minerals and Natural Gas', Global Research, February 21, 2014 (https://www.globalresearch.ca/the-war-is-worth-waging-afghanistan)

[16] T. Janus (2012): 'Natural resource extraction and civil conflict', Journal of Development Economics, 97, 24-31.

[17] Ashraf Ghani and Clare Lockhart (2009): "Fixing Failed States: A Framework for Rebuilding a Fractured World", Oxford University Press.

[18] Edward Gibbon (1906): The History of the Decline and Fall of the Roman Empire. This Fred de Fau and Co. (New York) 1906 edition was published in 12 volumes and edited by J.B. Bury with an introduction by W.E.H. Lecky. Of the original 6 volumes set, volume I was published in 1776, volumes II and III in 1781 and volumes IV, V, and VI in 17881789.

[19] Thomas Piketty (translated from the French original by Arthur Goldhammer) (2014): Capital in the Twenty-first Century, Belknap Press: An Imprint of Harvard University Press, 704 pp.

[20] Craig Whitlock and The Washington Post (2021): The Afghanistan Papers - A Secret History of the War (Simon \& Schuster: ISBN13: 9781982159009)

[21] Jonathan Lee (1991): 'Abd al-Rahman Khan and the maraz ul-muluk', Journal of the Royal Asiatic Society, 1, p. 209-242.

[22] Arka Biswas (2013): Durand Line: History, Legality and Future, Vivekananda International Foundation, Occasional Papers, September 2013 (accessed at https://www.files.ethz.ch/isn/170887/Durand\%20Line_History\%20Legality\%20\%20Futu re_Final.pdf on Sept 12, 2021) 
[23] Samuel Huntington (1996): The Clash of Civilizations and the Remaking of World Order, Simon \& Schuster (ISBN13:『 978-0684811642).

[24] Francis Fukuyama (1992): The End of History and the Last Man, Free Press (ISBN13: 978-0743284554)

[25] Ninha Dagia (2021): "Tehreek-e-Labbaik Pakistan Again Signals its Street Power", The Diplomat (https://thediplomat.com/2021/10/tehreek-e-labbaik-pakistan-again-signals-itsstreet-power/)

[26] CNN Business (2021): " UN to Elon Musk: Here's that \$6 billion plan to fight world hunger" (https://www.cnn.com/2021/11/18/tech/elon-musk-world-hunger-wfpdonation/index.html)

[27] Ahsan Butt (2021): "Imran Khan's talks with the Pakistan Taliban will not bring peace", Al Jazeera (https://www.aljazeera.com/opinions/2021/10/27/imran-khans-talks-with-thepakistan-taliban-wont-work)

[28] Shoaib Ahmad Rahim (2018): "Afghanistan's Dependence on Pakistan: Trade, Transit and the Cost of Being Landlocked", Kardan Journal of Economics and Management Sciences 1(4) 1-21 (https://kardan.edu.af/data/public/files/KJEMS-4th-3.pdf)

[29] 'Abd al-Raḥmān Khān (1900): 'The Life of Abdul Raḥmān Khān, emir of Afghanistan' (Ed: Sultan Muhammad Khan, Publisher: John Murray, London) (https://www.wdl.org/en/item/17693/\#)

[30] Connor Bulgrin (2020): When Aid Replaces Ideology: Corruption as a Hegemonic Device in Post-Taliban Afghanistan; Research Thesis, Ohio State University. Accessed at https://kb.osu.edu/bitstream/handle/1811/92083/connor_bulgrin_thesis.pdf?sequence=1 (retrieved on Sept 14, 2021). 